\title{
Interview on biosemiotic ethics with Wendy Wheeler
}

\author{
Jonathan Beever, University of Central Florida \\ Morten Tønnessen, University of Stavanger \\ Yogi Hale Hendlin, University of California
}

\begin{abstract}
Summary. In this interview, Wendy Wheeler, London Metropolitan University Emerita Professor of English Literature and Cultural Inquiry, discusses her thoughts on biosemiotics and its relevance for ethics. In Wheeler's perspective, biosemiotics can ground ethics because it offers an alternative and fitting ontology of relations. She shares her thoughts on Peirce as a foundational figure for biosemiotics, and explains why she doubts that an ecological ethics can be framed in terms of laws. Further, she discusses her views on moral agency in nonhumans, and warns against ideas based on human exceptionalism, sentimentalism and puritanism. Wheeler thinks that a biosemiotic ethics can posit a more located, or systemically nested, sense of semiotic value. Her moral question, she explains, would always be something like: Is this growing? Is this lively?
\end{abstract}

Zusammenfassung. In diesem Interview diskutiert Wendy Wheeler, emeritierte Professorin der englischen Literatur- und Kulturforschung an der London Metropolitan University, ihre Gedanken zur Biosemiotik und deren Relevanz für die Ethik. Nach Wheelers Verständnis kann Biosemiotik eine Ethik begründen, weil sie eine alternative und angemessene Ontologie der Beziehungen bereithält. Sie erläutert ihre Gedanken zu Peirce als einer der Gründungsfiguren der Biosemiotik und erklärt, warum sie an der Möglichkeit einer gesetzlichen Rahmung der ökologischen Ethik zweifelt. Darüber hinaus diskutiert sie ihre Ansichten zur Möglichkeit moralischen Handelns in nicht-menschlichen Organismen und warnt vor Konzepten, die auf menschlicher Ausschließlichkeit, Sentimentalität und Puritanismus basieren. Wheeler ist der Auffassung, dass biosemiotische Ethik ein stärker eingegrenztes, oder systemisch geschachteltes Konzept von semiotischem Wert postulieren kann. Ihre moralische Frage, so erklärt sie, würde stets in etwa so lauten: Wächst es? Ist es lebendig? 
I.

JB: Thinking about contemporary changes to the directions of animal and environmental ethics in the era of the Anthropocene and age of ecology, what strategies or theoretical frameworks do you think have the most potential for solving applied ethical problems involving nonhuman animals or nature?

WW: Biosemiotics and an ontology of semiotic relations, obviously!

JB: But what about biosemiotics gives it potential? It seems like there are still many conceptual and structural problems to solve before biosemiotics becomes more widely accepted and impactful. And what's so important about an ontology of relations? Why not just describe scientifically the ways things do indeed relate "out there" in nature and leave ontology and conceptual schemata aside?

WW: As it is currently practiced (on the model of physics and reductionism), science, which only deals with material particulars, cannot - as I argue in my chapter on the influence of gnosticism on modern science in Expecting the Earth - offer us an account of relations at all. Neither can it offer us an account of immaterial causes, such as semiotic causes, of which relations are the prime example. The Latins knew it. Charles Sanders Peirce (who read them) knew it. Gregory Bateson (who read Peirce) knew it. Biosemiotics knows it. I think it's a good idea to stay as close to science as possible. Jesper Hoffmeyer's work is an excellent example of this, as is Terry Deacon's. However, and as wonderful and orientated to the facts of the case as it is, science always has more to do. I take Peirce's model of science as "the Path of Inquiry" here. Thus I do, as a matter of fact, think that the scientific approach is radically inclined to bring us closer to the truth of the case, but - as is well known by philosophers of science - science is not wholly separable from the culture in which it has grown.

For example, in Western cultures, both science and political formations are profoundly influenced - in ways they do not even discern - by the Christianity in which these cultures have been born. Paul Davies makes this argument in his chapter in Information and the Nature of Reality: From Physics to Metaphysics. Hilaire Belloc makes a similar case, in his The Great Heresies, for understanding the whole cultural significance of heresies in the shaping of human self-understanding and its practice in terms of political goals. And this is so even where the heresies concerned do not (as they generally don't) know that they spring from heresies born centuries before them. Sometimes, in order to progress, science must shake itself up. For that, new conceptual schemata, and a different grasp of the ontology of all living organisms as interpretive makers of their worlds, not as machines but as a kind of living poetry (as biologist James A. Shapiro has put it also), must take place. Biosemiotics is a part of that shaking up. 
II.

JB: In your 2006 book The Whole Creature: Complexity, Biosemiotics and the Evolution of Culture, you recognize the biosemiotic thesis that semiosis is "built into nature, and we are the animals in whom it has most richly flourished, and who have moved from what we call nature to what we call culture - though they are differences only of gradation in the direction of complexity and conceptual abstraction" (p. 153). Do you see this ontological view as catalyzing the conception of a biosemiotic ethic? If so, how? How does this differ from standard anthropocentric readings of ethics?

WW: In my recent monograph, Expecting the Earth: LifelCulturelBiosemiotics, I emphasise that semiotics (and biosemiotics of course) involves an ontology of (sign) relations. How we conceptualise other non-human organisms, and our human selves among them, seems to me to be at the heart of a pragmaticist ethics. Once we understand our interdependence in these terms, as the necessary co-evolutionary co-dependence of life that flows cybernetically around and through other life, I think we must eventually learn that life is made of trillions of conversations between the living and the dead and the yet to be born. Especially via such ecological matters as the forms of microbiota, and the many things we are only just beginning to understand, but upon which all our nonhuman and human lives depend, such as the richness of bacterial and genetic horizontal transfer, and the flows of which we cannot calculate. This will certainly make us develop new ethical principles. This makes a dialogic approach central. But, of course, a semiotic pragmaticist understanding recognises that dialogue isn't only, or even mainly, in words. It is in the differences dialogue brings about. Impoverished diversity means fewer 'conversations'. The fewer such 'conversations' there are, the more we are in danger of what Ivar Puura called semiocide: the collapse of ecological systems both natural and then cultural. ${ }^{1}$

JB: I hear bits of C.S. Peirce coming through in your very specific use of "pragmaticist" in describing ethics - of course, although he grounds much contemporary theory, Peirce himself was no biosemiotician. Indeed, it's not clear that he thought reconceptualizing non-human organisms was an important part of pragmaticism's project. What's your read on the importance of Peircean pragmatism, specifically?

I could hazard a guess, in answer to my own question: you talk beautifully in terms of the trillions of conversations about what others see as ecological relations and what Peirce saw as the endless process of semiosis: is this the sort of thing from which new ethical principles might develop? If so, what might they look like (the million dollar question!)?

WW: I think that Peirce did think about non-human semiosis, and that he thought it was important. There's the letter to Lady Victoria Welby of December 1908 (EP2.478), isn't there, in which he defines the sign in terms of 
relations, and complains about the confusion made between "interpreter" and "interpretant". The latter word has been chosen because he doesn't want to imply that interpretation is only a human accomplishment. As we now know from the scientific work of biosemioticians (and many others), interpretance is a vital capacity of all organisms, right down to bacteria and cells. Indeed, semiosis (sign use) may define life itself. In the letter he talks about the relations between interpretant and object as one in which the latter mediates the former as much as it determines (although not perhaps in an entirely strict sense) an "effect upon a person". He then goes on immediately to say that his insertion of "upon a person" is "a sop to Cerberus, because I despair of making my own broader conception understood". In other words, he doesn't think that only persons use signs and develop interpretants. At this point in the early 20th century, and although Peirce had talked about the entire universe being perfused with signs and interpretation, he knew that suggesting that animals and plants and other organisms were active users of signs would be unthinkable for most scientifically inclined people. In the 1906 essay "The Basis of Pragmatism in the Normative Sciences", Peirce noted:

It seems a strange thing, when one comes to ponder over it, that a sign should leave its interpreter to supply a part of its meaning; but the explanation of the phenomenon lies in the fact that the entire universe, - not merely the universe of existents, but all that wider universe, embracing the universe of existents as part, the universe which we are accustomed to refer to as 'the truth', - that all this universe is perfused with signs, if it is not composed exclusively of signs.

Now, this might seem at first blush a little different from the focus of the pragmaticist idea, but I don't think it is really. An understanding of sign use, and the relational biosemiotic ecology of the living, may give us a strong clue about what a biosemiotic ethics might look like. First, the meaning of something is what it does, what it achieves or how it functions. Thus the "meaning" of legs is "the capacity for walking, running, hopping, and so on". The context will supply the nuance, and we should really notice the teleological aspect also. Pragmaticism is about what can, and is likely to, be achieved or done in our most realistic assessments of any actual case of sign use. This is close to Merleau-Ponty's sense of phenomenological being not simply as an "I think" divorced from always active bodies, but, more pragmatically, as an "I can". This has a distinctly pragmatic and also ethical implication. I sometimes think we humans allow ourselves to be overly distracted by words. Yet, if you want to know the meaning of something, you must ask what it is actually and pragmatically likely to achieve. People are very good at providing justifications and confabulations for things they have said. But the real meaning of a meaning lies in how it is likely pragmatically to function. I wish this question was more frequently asked of people agitating for this or that cause, including politicians and other policy makers. Thus I am interested in an ethics built around what can be, and is likely to be, achieved. I'm not inte- 
rested in any puritanism of "you must" or "we must" that has not asked itself some serious questions, given everything we know about humans and other organisms, about what effects are likely to be brought about by this or that injunction. Ethical behaviour, like political policies, surely owes us all the respect of asking what will be brought about by a rule, law or policy.

Second, I'm not at all sure that an ecological ethics can be framed primarily in terms of law at all. In Peirce's schema, this would be putting the cart before the horse. The Peircean categories, its order of being, is as follows: aesthetics (Firstness: feeling), from which springs ethics (Secondness: resistance and counter resistance, the struggle of enworlded being), followed by the taking of habits (Thirdness) which importantly include the necessary habits of communication. Law is one way of describing habit, but it may not be the most helpful one, not least because habits of communication grow organically, while modern (at least) ideas of law, as regards ethics, can simply be imposed - supposedly rationally, as though conscious reasoning is all there is to be said about knowing. I am much more interested in this way of thinking the organic emergence of life and its capacities than in the enunciation of desirable laws which may be very narrow, or just an historically circumscribed way of claiming "virtue positions". The latter are often really just 'positional goods', i.e., about the selves making them and not about others at all. Human abstract thought is a wonderful thing, but sometimes it simply runs amok because its forgets that it is tied, by the chains of semiosis you mention, to all our (and other organisms') other semiotic relations - aesthetics, ethics, habit - in an emergent process. I sometimes despair at human stupidity. Do I think that a better understanding of the perfusion of semiosis, and of a pragmatic understanding of sign use, would improve things? Yes, I do. I have more to say about this, but I will wait until answering your question 4 .

III.

JB: Your work seems to support the view that some animals, based on their capacities and practices, have moral agency; and that, as a result, we human animals have ethical obligations to them. What, in your view, is necessary to catalyze a biosemiotic ethics sufficient both (a) to acknowledge that some nonhuman animals have moral agency and (b) to evidence human moral obligations toward them? How does this view reflect a biosemiotic thesis?

WW: I think it's simply remarkable that we, as a species, have managed to hang on for so long to the idea that animals (and even plants, albeit strangely and slowly and through their root systems and symbiosis with fungi) don't have intentional experience. Does anyone who has a pet, or works with animals (except in the most alienated, factory farming way) actually believe this? I am not sentimental about life, or about nature generally which is tough and harsh - but it seems clear to me, not least for the prag- 
maticist reasons I gave above, that we have a general obligation, as thoughtful and reflective animals, to be responsive to the life around us. "Responsive" shares the same root meaning as responsible. It is true that "no man is an island, each is a part of the maine" as John Donne said in one of his devotions in 1623. "If a clod bee washed by the sea, Europe is the less". We could rewrite that to say, rather less poetically, that no form of life is an island. Jesper Hoffmeyer has suggested that we might think of a sort of hierarchy of moral regard based on the idea of 'semiotic freedom'. I think that is, in fact, generally how we function; we are less worried about treading on ants (not much semiotic freedom) than on dogs or cats (quite a lot of semiotic freedom). Ethologists have showed us that some animals also have a sense of fairness. I like the film of a monkey hurling away a piece of inferior food, a carrot perhaps, when she or he sees that the monkey next door has been 'paid' a grape (far superior) for accomplishing an identical task. I think - and I don't want to anthropomorphise beyond the bounds of sympathetic reason - that some animals will also help other animals when they're in trouble. I think we can be responsive to all life forms, and particularly careful perhaps with those in which we recognise a primitive sense of moral agency and fellow feeling. All these things are based on a biosemiotic recognition of forms of intentionality and agency, however moderate.

IV.

JB: Where do you see the demarcation line for a biosemiotic ethics, with regard to attribution of moral status? Higher mammals? Animals generally? Species, ecosystems? Life itself? Indeed, in the contemporary philosophical ethics literature there seems to be a resurgent interest in the moral value of life itself as the limit of moral extensionism. What missteps, if any, do you see this naturalistic extensionism making?

WW: I think what is to be avoided is sentimentalism, which is the cloying side of Puritan cultures profoundly affected by the Protestant Reformation such as ours. I would certainly say that all life is properly worthy of our regard and care, but I wouldn't understand care to exclude hunting or meat eating, or to involve hurting or otherwise punishing human animals for being the animals humans are. I can't bear the repulsive obsession with 'purity' and 'virtue' that one sees all over the place in various cultures these days. It's a form of religious fundamentalism. Green puritan fundamentalism is just as repulsive as any other kind. It's important to stay with the science, and not to be distracted by quasi-religious impulses. I do, in fact, think that reverence for the miracle of life, a sort of cosmic consciousness, is an important aspect of ecological thinking. I just prefer it to know what it is. I heard one biologist describe life as a great conductorless orchestra. One can be deeply moved by the music of creation without becoming sentimental or idealising or anthropomorphicising other organisms. 
JB: It is clear from what you said about Hoffmeyer's idea of semiotic freedom that all life - even plants - are owed s o m e moral regard based on their biologically/culturally bounded capacity for entering into semiotic relations with others. But, Western philosophy at least has understood moral status as something special: based on a capacity or characteristic that binds us in the same way we are bound to each other to that individual. Even the sentience theorist, who posits moral regard owed based on the individual's abilities, holds that causing suffering to a human or nonhuman is equally wrong. But what you posit is not that sort of thing: it's a moral status that extends different care to different individuals based on how semiotically free they are. And that view seems to want to include hunting as analogous to punishment for human animals: a suffering we cause for morally-acceptable reasons based on some unethical action on the part of the sufferer. So let me push just a little: do you see biosemiotics ethics as radically different in that it extends care in the ways you've described, or is it instead more like sentience theory which proposes some form of stopping place for "full" moral regard?

WW: I think I may have been less than clear on the hurting and punishing human animals point. I meant that we are animals, and I can't see any intellectual clarity (whether in radical animal liberation or in human abortion debates) in hurting one kind of animal because it has made choices (no matter how much one may disagree with them) in regard to another living thing - whether lab rat or foetus. On your other points, as I said, in practice we do make hierarchical distinctions (bacteria, ants, chickens, horses, dogs). Trying to eliminate that seems to me to put yourself on a hiding to nothing. Nothing will be achieved because the alternatives fail to take pragmatic account of how human animals are actually inclined to behave, albeit within naturally and culturally shaped parameters - i.e. there is certainly room for movement, but those histories and umwelten are re al makers of their organisms, and can't just be excised or reasoned away.

But there's a more fundamental point I should make about how I think about a biosemiotic ethics. This is that the nature and extent of semiotic freedom cannot be unhooked from umwelt, from context that is, and from the whole ecology of biosemiotic relations upon which life is dependent. Our Western cultures are highly individualistic, but I think that a biosemiotic ethics would posit a more l o c a te d, or at least systemically nested, sense of semiotic value. The Australian eco-philosopher Freya Mathews is very useful here. Freya wrote a very good article, "The Anguish of Wildlife Ethics" for the journal New Formations no. 76 in August 2012. In it, she noted the distinction and tension between animal ethics and ecological ethics. Basically, this tension exists between the valuing of animals as individuals versus valuing the whole ecological system in which it might be necessary for humans to take on the systemic responsibility for culling, predating or otherwise killing individual animals in order to maintain the health of the system as a whole. This is particularly the case where humans (sheep 
farmers in Australia provide Freya's example) have got rid of the top natural predator (dingoes) of another species (kangaroos) in order to protect their sheep herds. This alternative ecological ethics is not really susceptible to context-free, supposedly individualistic rationalist utilitarian arguments. The American environmental philosopher Baird Callicott opposed this individualistic rationalist ethic to Aldo Leopold's land ethic, for example. The latter, of course, is concerned with the health of whole systems. Callicott called the rationalist system "moral individualism" and the whole system regarding view (one that, note, has the aesthetic noticing of significant patterns in the system for making judgements about its best behaviours and preferred ways of autopoiesis) "moral holism". This view - which begins with aesthetics (Firstness) as distinct from the rationalist one which begins with law (Thirdness) - places moral value on whole systems of relations and upon context. Thus, one cannot generalize about species, and individual members don't matter so much as the overall eco-system. Species which might be highly valued in one umwelt may not be valued in another.

This view seems to me to be supported by a biosemiotic systems view of relations. Freya discusses this whole system ecological ethic in some detail in her essay, and then goes on to enlarge upon this theme by drawing a distinction between axial and de ontic normative ethical conceptions. I think it would be testing the boundaries of the $Q$ and $A$ form to go into the detail of these arguments here, but I recommend Freya's article for reference. These arguments are very interesting from a biosemiotic perspective, especially since they take an implicitly semiotic point of view on the constitution of the individual organism - not as a possessor of essential qualities, but rather, as the bearer of semiotic capacities which are activated or opened up by the species' umwelt. This is at one with a biosemiotic view of all selves and minds. These arise, themselves on the structure of the sign, from the relation between a body with a memory capacity and a world. Selves and minds are not things, but relations. This would also be a part of the motor of evolutionary change. Biosemiotics shares its dislike of "interiority" with Gilles Deleuze and Félix Guattari, and its understanding of the processes of potentialities becoming actualities with Gilbert Simondon's ideas of "dephasing" and "individuation".

Axial ethics belong to civilizations developing during the great Axial Age (roughly 900 to 200 B.C.). Deontic ethics belong to an earlier huntergatherer period. As Freya writes, discussing Australian aboriginal deontological ethics by way of an example, here "law" is not "law" in the Axial sense of rationally arrived at, and equally true at all times for every "individual" that falls under its remit of rational and proper empathy or fellow feeling. With this, you do not run into the problem of a hierarchy of what is really a false and unsustainable empathy in which we cry for the suffering of ants or microbes as a matter of course on every occasion. Thus Freya writes: 
Law is not ethics in the axial sense. It is not a practice of empathy attuning us to the feelings of others as individuals and thereby instilling in us a compassionate concern to promote their interests and protect them from suffering. Law is ontological: it identifies the patterns in things that enable the living cosmos to renew and re-articulate itself in perpetuity. Law furthermore spells out how people can participate in this pattern. It emphasizes that it is the living cosmos that has given people existence and it details what people owe the cosmos in return, what they need to do ought to do - to ensure that this generative order is perpetuated. Law is in this sense deontic rather than ethical - it is about duty and obligation, setting out an order of grave imperatives that transcend compassion (Mathews 2012: 125).

I think this is profoundly biosemiotic. But it may be important to meld it to the hierarchy of semiotic freedom. I don't think we can escape the position of judgement and some mastery in which we humans find ourselves. You can see why Heidegger named Dasein as the shepherd of being. I certainly do want to value individual humans, or orangutans or apes or dogs or horses more than I value individual house flies. Decisions made about how humans fit into the pattern raise the question of what counts as a reasonable model of the holistic pattern. This is a very difficult question. Get it wrong, and you have totalitarianism and the willed death of millions under National Socialism. On the other hand, the constant evocation of compassion as a source of law in our culture is a problem. The political left is predicated upon it constantly, but it is a heaven on earth which can never be achieved. It is in fact inhuman. It has also led, as we know from the politics of the twentieth century particularly, but also from earlier, to utterly inhuman behaviour and the killing of millions of human animals. The moral holism of regarding what Gregory Bateson called "the patterns which connect" the whole system and their necessary maintenance in a living cosmos seems more preferable, but the ethical biosemiotic model for this will require a lot of very careful thinking. I am not, of course, arguing against fellow feeling; but the constant demand for feeling, for the right amount of feeling and for the right causes, is both open to abuse and also inhumanly exhausting. It is a demand to be a saint. It is a humanism turning into the inhuman. Perhaps I should add that, of course, all this needs to be argued through, subjected to objections and thus refined. The "Path of Inquiry" must remain open.

\section{V.}

JB: Biosemiotics offers a theoretical frame to distinguish living organisms from abiotic nature, given that it postulates that all living beings relate to meaning via signs of some form. Several contemporary scholars have asked whether and in what way this biological and semiotic theory might help justify the attribution of moral value to all (and only) living organisms and systems. Do you see naturalistic justifications for moral worth such as this as fruitful avenues of inquiry? 
WW: I've complicated matters in my new book by extending aesthetic then moral value to anything which, in the hands and minds of the living, remains itself alive, and is capable of growth. Thus, I write about art and technology (as long as they are living and growing) as having a life in culture just as organisms have a life in culture and nature. My biosemiotic and Peircean criteria are lifefulness and the capacity for growth - especially the growth of knowledge, although I don't think that is simply a cerebral affair by any means. By this reckoning, a village or a city is like a living organism. So is (at best) an economy. I don't want to break culture from nature. I think we would do much better, and act with moral care, if we extended our sense of what constitutes that striving quality of living things. My moral question would always be something like: is this growing? Is this lively? But I would also want to bear in mind the important point that Jesper Hoffmeyer, and Terry Deacon especially, in his 2012 monograph Incomplete Nature: How Mind Emerged from Matter, make about the need for constraints. Various forms of boundaries and natural and cultural prunings are also necessary to lifefulness, as is an extension of our understanding of mind and of being as including a shaping relation to and from the natural and social environment. Invasive species may be very lively, but also may wreak environmental havoc. I think we've done some absolutely pathological developmental things (with our children, for example) because we haven't properly understood that flourishing requires both constraints and an umwelt which is the source of semiotic legibility. The implications of this for humans may prove very difficult, exceptionally hard to discuss; but we must be able to discuss them, and to think them through, or else there will be ecological, natural and social, chaos. I think we are already seeing this socially and politically. Attending to the experience of environments and organisms under pressure by attending to the semiotic relationships within them cannot exclude humans. Failure to have these aesthetic, ethical and political conversations will only lead to more profound and destructive perturbation.

\section{Notes}

Cf. Puura (2013) and Maran (2013).

2 https://www.Iwbooks.co.uk/sites/default/files/nf76_09mathews.pdf

\section{References}

Belloc, Hilaire (1938) [2015], The Great Heresies. Milwaukee: Cavalier Books.

Davies, Paul (2010), Information and the Nature of Reality. Cambridge: Cambridge University Press.

Deacon, Terrance (2012), Incomplete Nature: How Mind Emerged from Matter. New York: W.W. Norton. 
Donne, John (1923) [1999], “No Man is an Island”. In: Devotions Upon Emergent Occasions and Death's Duel. New York: Random House.

Maran, Timo (2013), "Enchantment of the Past and Semiocide: remembering Ivar Puura". Sign Systems Studies 41, 1: 146-149.

Mathews, Freya (2012), "The Anguish of Wildlife Ethics". New Formations 75: 114-131.

Peirce, Charles S. (1906) [1998], "The Basis of Pragmatism in the Normative Sciences". In: Essential Peirce. Volume 2. Bloomington: Indiana University Press: 371-397.

Peirce, Charles S. (1908) [1998], "Letter to Victoria Welby". In: Essential Peirce. Volume 2. Bloomington: Indiana University Press: 478.

Puura, Ivar (2013), "Nature in our Memory". Sign Systems Studies 41, 1: 150-153.

Wheeler, Wendy (2006), The Whole Creature: Complexity, Biosemiotics, and the EvoIution of Culture. London: Lawrence and Wishart.

Wheeler, Wendy (2016), Expecting the Earth: Life/Culture/Biosemiotics. London: Lawrence and Wishart.

Prof. Jonathan Beever, Ph.D.

Department of Philosophy

University of Central Florida

4111 Pictor Drive, Orlando

FL 32816, USA

E-Mail: jonathan.beever@ucf.edu
Prof. Morten Tønnessen, Ph.D. Department of Social Studies

University of Stavanger

4036 Stavanger

Norwegen

E-Mail: morten.tonnessen@uis.no

Yogi Hale Hendlin, Ph.D.

Department of Medicine

University of California, San Francisco

530 Parnassus Ave., Suite 366

San Francisco, $C A$

94143-1390, USA

E-Mail:yhh@yogihendlin.com 